\title{
Haitian Creole Language
}

National Cancer Institute

\section{Source}

National Cancer Institute. Haitian Creole Language. NCI Thesaurus. Code C153942.

A French-based creole language native to Haiti. 